\title{
HUMAN HABITATION ENHANCES SPECIES DIVERSITY : TRENDS OVER THREE DECADES OF CBCS AT THE APEX OF PALLISER'S TRIANGLE
}

\author{
JAMES K. FINLEY and KIM B. FINLEY, Box 36, Luseland, Sask. S0L 2A0
}

In 1982, we wrote an article for Blue Jay entitled "A decade of Christmas bird counts in the aspen parkland." We concluded after the first decade that our surveys provided a "reasonable index of winter bird life from which we can now begin to look for trends." In those days, a decade seemed much longer so it is with some surprise that we find ourselves looking back over the last three decades with greater hindsight and a dash of humility.

Our title was misleading; the plain fact is that we're at the margin of the aspen parkland, forty miles due south of the apex of Palliser's Triangle (Fig. 1) ${ }^{9}$ This was the

Figure 1. Luseland, situated beneath the apex of Palliser's triangle

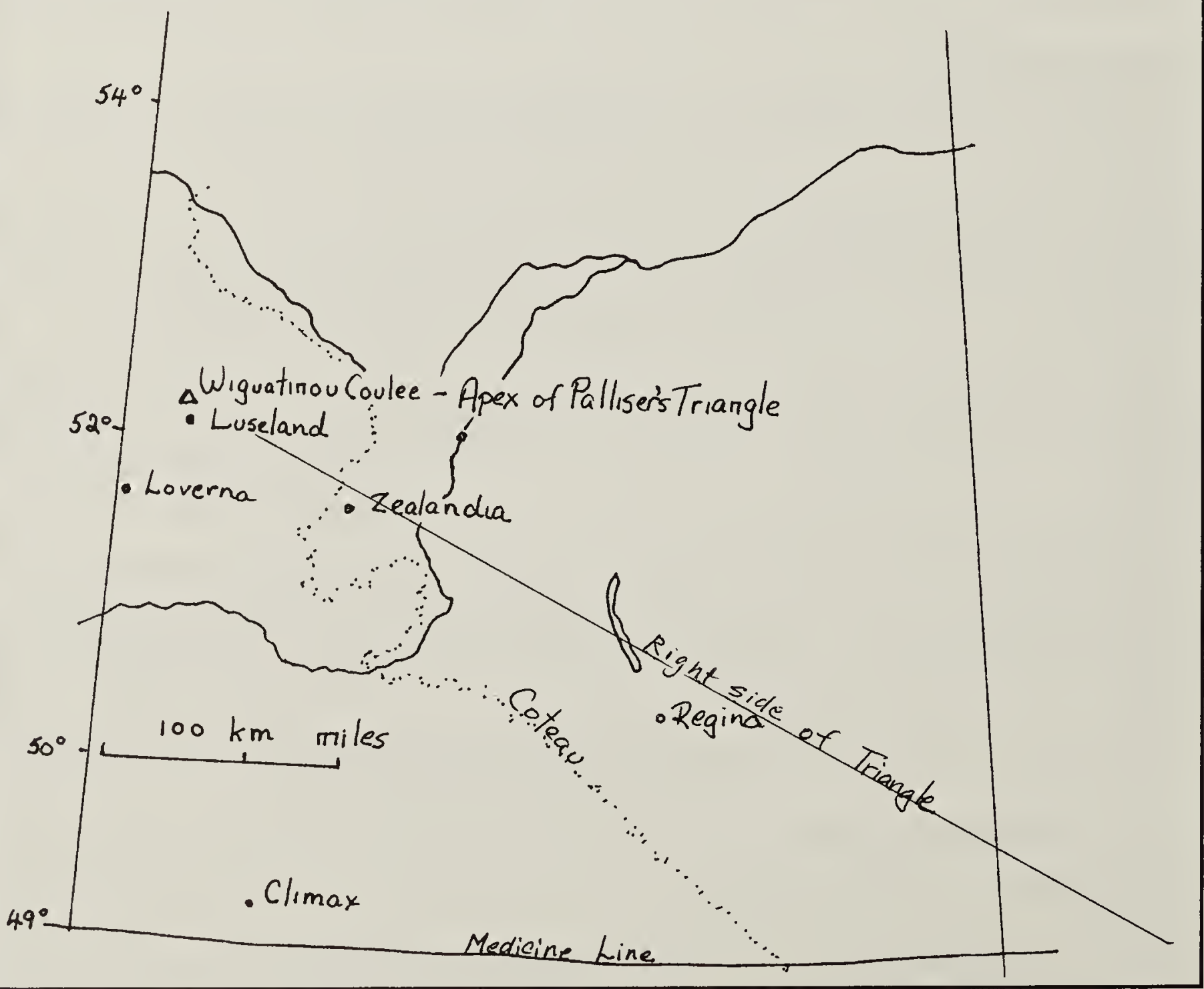


country that naturalist John Macoun ardently believed would benefit from the "civilizing influence of the plough." his glowing appraisal that the Canadian government was sold on and his Edenesque picture that drew our forefathers into the infamous triangle. We're the third generation removed from these sodbusting pioneers, inheritors of a regional natural history that extends from homesteads at Climax, at the base of the triangle, to Zealandia, Loverna and Luseland, ${ }^{5}$ a triad of dead or dying settlements at the apex. Luseland, latitude $52^{\circ} 05^{\prime} \mathrm{N}$, is surrounded by a lacustrine plain to the south, and low relief hummocky terrain between two main glacial valleys. The area was settled between 1907 and 1910 by various Slavic and Anglo-American cultures. The town currently has a population of around 600 and has been slowly declining, like most prairie towns, over the last three decades.

Less than a century ago, this region was a mosaic of fescue and mixed-grass prairie, maintained by buffalo and fire. The first settlers had to travel forty miles west to Sounding Lake, Alberta to find firewood. After settlement and fire suppression, aspen advanced quickly and established itself in moister pockets of hummocky terrain. This succession is well illustrated in early photographs. ${ }^{5}$ Today, although some areas resemble parkland, aspen groves usually account for less than $10 \%$ of the vegetation cover. Remnants of mixed-grass prairie exist, somewhat ironically, mostly in the RM of Progress PFRA pasture. Except for a few coulees, fescue grassland has been almost eliminated. Over $90 \%$ of the land area has been highly altered from its native state and is maintained at a pioneering level (like the first stage after glaciation, volcanism or fire), a juvenile ecosystem where "weedy" species prosper.

The area is dominated by cereal monoculture subject to changing economies of scale, rapidly-changing farming practices and rural depopulation. Crop diversity has increased dramatically since 1970 , with canola, mustard, pulse seeds, sunflower and canary seed being cultivated. Abandoned farmsteads are numerous, usually every half section. Luseland once boasted six grain elevators, now replaced by two large elevators, one of them a concrete monolith. In the surrounding area, Superb, Major, Reward, Revenue, Onward, Hearts Hill, echo Macoun's enthusiasm, whereas Cactus Lake and Tramping Lake sway to Palliser's tune. Baliol and Salvador are more enigmatic. Most are depopulated, and except for the Caraganas and Manitoba Maples, Hearts Hill and Baliol are all but invisible, expunged from the maps.

Agricultural settlement of the prairies, one of the most rapid and expansive conquests in history, has generally been regarded as anathema to species diversity. While it's true that a vast area of native prairie has been destroyed, and with it some of the endemic species, human cultural practices have, in fact, created greater habitat diversity, resulting in more bird species than could exist in the natural state. While monoculture, by nature, greatly reduces species diversity, its subsidiary or side effects can enhance diversity. Though some would argue that sparrows, pigeons, and starling are about as culturally diverse as a Big Mac, they are well adapted, andlike it or not-pugnacious survivors. (Without the chirping of House Sparrows, a prairie town or farm would be oppressively quiet in winter.)

\section{Methods}

Our methods are crude but fairly consistent in terms of observer experience and continuity. Usually the count occurs on Boxing Day or the day after New Year's. In Luseland, we take a morning stroll through town and the elders keep watch at bird feeders throughout the day. Typically, two parties scour the country in vehicles within a 7 -mile radius, covering about 75 miles. We walk through aspen groves and abandoned farmyards, monitored in 
previous years, usually covering 5-10 miles. The count always includes "Williams Pasture", an area of mixed-grass prairie in the PFRA pasture, and a small acreage of fescue grassland at "Birks Grove."

\section{Results}

An average of 14 species (SD 2.6) was recorded on the 30 counts. Thirteen species were observed on more than $70 \%$ of the counts; six of these (Gray Partridge, Rock Dove, House Sparrow, Black-capped Chickadee, Magpie, Snow Bunting) occurred on practically all counts (Table 1).

The average number of species increased by about two over the three decades : 13.5 \pm SD 2.2 in the 1970 s, $14.9 \pm 2.8$ in the 1980 s, $14.9 \pm 2.7$ in the 1990 s. Blue Jays began appearing regularly in 1977. Hairy Woodpeckers first appeared in 1982 and Red-breasted Nuthatches, only in the last decade. Starlings, Cedar Waxwings and Merlins waxed and waned during the middle decade. Sharp-tailed Grouse, Pine Grosbeaks, Bohemian Waxwings, Northern Shrikes and Horned Larks declined in frequency over the period.

A province-wide assessment made in 1986 found that four species represented $78 \%$ of observations made on provincial bird counts - House Sparrow 31\%, Snow Bunting 28\%, Bohemian Waxwing 10\%, redpoll sp. 9\%. ${ }^{8}$ These same four represented $82 \%$ of our numbers but in different proportions $-21,45,5$, and $11 \%$, respectively. (These top four accounted for only $60 \%$ of total numbers recorded provincially in $2000 .{ }^{4}$ )

The abundance of most species was quite consistent over all decades, though there was considerable yearly variation in redpolls, Snow Buntings and Bohemian Waxwings. Numbers of Black-capped Chickadees and Blue Jays increased since the first decade, and magpies have increased in the last decade. Peak numbers of Redpolls in the last decade were due to invasions in
93 (205), 95 (457) and 99 (519). Sharptailed Grouse declined noticeably in the last decade and were not seen on the last two counts.

In addition to the 22 species listed in Table 1, another 22 species were recorded on one or two counts. These are, in chronological order of appearance (asterisks indicate those species observed on two occasions): Western Meadowlark, Goldencrowned Kinglet, Evening Grosbeak*, Sawwhet Owl*, American Tree Sparrow*, White-breasted Nuthatch, Spruce Grouse, Prairie Falcon, Gyrfalcon, Northern Harrier, Brown Creeper, Common Grackle, Northern Flicker, Gray Jay, Short-eared Ow1, Golden Eagle, Bald Eagle, Red Crossbill, Townsend's Solitaire, Song Sparrow, Common Raven* and Purple Finch. Remarkably, we continue to add a new species almost annually.

\section{Discussion}

So, other than an excuse to get outdoors and escape from cold turkey, what does this annual madness mean?

Representation: Although the methodology is crude, it's robust enough to provide a consistent index. This is due to observer experience, continuity and behaviour (slothful creatures of habit), but, more importantly, it's due to the fact that in winter birds have few places to hide. Poor counts occasionally occur due to severe weather conditions, limited coverage or few observers.

Our census provides an avifaunal signature representing the apex of Palliser's Triangle specifically, and Saskatchewan in general-the 16 most frequently recorded species were, with one exception, the same ones recorded on all provincial counts between 1942 and 1976. ${ }^{7}$ This is because we're on the fringe of the parklands and the provincial compilation is a mix of prairie and parkland sites. The exception was the Horned Lark which ranked 11 th on our list 
Table 1. Frequency and average count of bird species recorded on three or more counts, by decade, 1971 - 2001.

\begin{tabular}{|l|r|r|r|r|r|r|r|}
\hline & \multicolumn{3}{|c|}{ Frequency } & \multicolumn{4}{|c|}{ Average number ** } \\
\hline & \multicolumn{1}{|c|}{70 s } & \multicolumn{1}{|c|}{ (0s } & 90 s & 70 s & 80 s & 90 s & All \\
\hline Sharp-tailed Grouse & 9 & 8 & 4 & 6 & 18 & 1.3 & 8.7 \\
\hline Gray Partridge & 10 & 9 & 9 & 23 & 37 & 28 & 29.3 \\
\hline Rock Dove & 10 & 10 & 10 & 25 & 37 & 41 & 34.1 \\
\hline Snowy Owl & 10 & 7 & 6 & 0.4 & 1.5 & 0.7 & 0.9 \\
\hline Horned Owl & 2 & 7 & 5 & 1.5 & 1.3 & 1.0 & 1.3 \\
\hline Downy Woodpecker & 8 & 6 & 6 & 0.7 & 2.2 & 0.8 & 1.2 \\
\hline Hairy Woodpecker & 0 & 6 & 7 & 0.1 & 1.5 & 1.4 & 1.0 \\
\hline Black-capped Chickadee & 9 & 8 & 8 & 4 & 12 & 10 & 8.3 \\
\hline Black-billed Magpie & 10 & 10 & 10 & 30 & 27 & 41 & 33.5 \\
\hline Blue Jay & 5 & 9 & 7 & 1.1 & 4.3 & 3.7 & 3.0 \\
\hline Bohemian Waxwing & 9 & 8 & 6 & 58 & 29 & 33 & 41.5 \\
\hline Pine Grosbeak & 4 & 3 & 1 & 7 & 2.8 & 2.1 & 4.0 \\
\hline Redpoll sp. & 10 & 7 & 8 & 56 & 59 & 154 & 91.3 \\
\hline Snow Bunting & 10 & 10 & 9 & 265 & 554 & 224 & 356.6 \\
\hline Horned Lark & 8 & 7 & 6 & 10 & 10 & 2.5 & 7.8 \\
\hline House Sparrow & 10 & 10 & 10 & 153 & 249 & 112 & 171.0 \\
\hline European Starling & 4 & 6 & 2 & 2.5 & 2.8 & 4.1 & 3.2 \\
\hline Northern Shrike & 3 & 1 & 0 & - & - & - & - \\
\hline Northern Goshawk & 1 & 1 & 1 & - & - & - & - \\
\hline Merlin & 0 & 3 & 0 & - & - & - & - \\
\hline Cedar Waxwing & 0 & 5 & 2 & - & - & - & - \\
\hline Red-breasted Nuthatch & 0 & 0 & 4 & - & - & - & - \\
\hline
\end{tabular}

* Number of counts per decade that the species was seen.

** Average number of individuals on counts in each decade.

Table 2. Some human cultural practices that affect species abundance, either negatively or positively.

\begin{tabular}{|l|l|}
\hline Sharp-tailed Grouse & Waste grain, PFRA management, predation by fox and owls \\
\hline Gray Partridge & Waste grain, shelterbelts, predation by fox and owls \\
\hline Rock Dove & Waste grain, abandoned buildings \\
\hline Snowy Owl & Vole eruptions, continuous cropping, global warming \\
\hline Horned Owl & Abandoned buildings and farmsteads \\
\hline Downy Woodpecker & Fire suppression, old growth aspen \\
\hline Hairy Woodpecker & Fire suppression, old growth aspen \\
\hline Black-capped Chickadee & Fire suppression, old growth aspen, bird feeders \\
\hline Black-billed Magpie & Cattle feedlots, burning ban in garbage dump \\
\hline Blue Jay & Bird feeders \\
\hline Waxwing sp. & Berry and crabapple trees, thermal shelter in Blue Spruce \\
\hline Pine Grosbeak & Abandoned farmsteads, decline of Manitoba Maple \\
\hline Redpoll sp. & Waste grain, screenings, weed seeds \\
\hline Snow Bunting & Weed seeds, continuous cropping, snow cover \\
\hline Horned Lark & Weed seeds, summer fallow, camouflage on gravel roads \\
\hline House Sparrow & Waste grain, abandoned buildings, concrete elevators \\
\hline European Starling & Garbage dump - ban on burning lifted in 2001. \\
\hline Merlin & Sparrows, thermal shelter in Blue Spruce \\
\hline
\end{tabular}


(18th on the provincial list), more indicative of the open prairie. Interestingly, in recent years, the top 16 species have changed somewhat; Common Ravens, Whitebreasted Nuthatches, and Ruffed Grouse have joined the top ranks. ${ }^{4}$

Our survey does not represent all habitats equally-it favours aspen habitatnor does it represent all species; Great Horned Owls for instance, which are always around, are difficult to detect because they are nocturnal. The census, particularly in the early years, was biased against House Sparrows, as they were considered a nuisance to count. This oversight is unfortunate because we have noticed a decline in these sparrows due to the loss of wooden elevators, use of metal granaries and fewer feedlots, that we are unable to quantify. A decline in sparrows, due to changing economies of scale, may explain why Merlins have not been seen in Luseland in the last decade, nor do they breed here like they used to.

Our survey results produce a consistent index that is representative of rural Saskatchewan. Urban centres, like Saskatoon and Regina, with their greater habitat diversity, dams and electrical generating stations, record more than twice the number of species seen in rural areas.

Habitat Complexity: We stated earlier that at least half the common species were highly dependent on the human cultural environment. ${ }^{1}$ This was an understatement - most or all of the species are dependent on the human cultural environment. Naturally, they wouldn't be caught dead on the bald prairie in midwinter. The "civilizing influence of the plough" has contributed greatly to habitat complexityfrom aspen groves, weed patches, shelterbelts from Caraganas to Blue Spruce, abandoned barns and granaries, spilled grain, weed screenings, bird feeders etc. (Table 2). Towns are virtual oases compared to the surrounding country.
In this highly altered landscape, few species are truly endemic in winter-perhaps the Snowy Owl and Snow Bunting-but even these have benefitted by our cultural practices. Snowy Owls benefit from vole eruptions when swathed fields are snowed under, and Snow Buntings feed heavily on weed seeds. Few other species on our list would be here if not for the human cultural environment-at first, an accidental by-product of civilization, more recently as a conscious effort. For example, before we initiated this census, very few people bothered to feed birds, now many have bird feeders, a behavioural change that has contributed to species diversity and abundance, e.g. jays, chickadees and nuthatches. In turn, farmers have benefitted by adding canary seed and sunflowers to crop diversity.

Although we inhabit a perpetually juvenile ecosystem, it also has mature and decaying elements that contribute to habitat complexity over time. Old, decaying aspen is favoured by woodpeckers and chickadees, and dead poplars and abandoned buildings provide cavities and thermal shelter for various species. We suspect that the arrival of Hairy Woodpeckers during the middle decade of our surveys was due to the maturation and decay of aspen groves. The present deep drought has killed more trees, ensuring future food and shelter.

In 1982, we noted that changing economies of scale manifest in rural depopulation, increasing farm size, feedlot size, and clearing of aspen groves and farmsteads, influenced bird abundance and species diversity. We sympathized with defenseless victims of this process, like chickadees and woodpeckers, as aspen groves were bulldozed during the halcyon seventies, when wheat was still king. In retrospect, they didn't need our sympathy; although farm size continues to increase, the practice of clearing aspen and breaking prairie has slowed in step with wheat prices, giving them a reprieve. Feeding stations have given them an even bigger reprieve. 
Predation: In 1982 we suggested that decimation of Coyotes by snowmobilers, and their replacement by Red Foxes in the late 1960 s, was indirectly responsible for the low abundance of Gray Partridge and Sharp-tailed Grouse, though our evidence was circumstantial, as our surveys began after the fact. ${ }^{1,2}$ Coyotes have increased markedly during the last decade and foxes have all but disappeared, as expected, but the anticipated rebound in upland game is not yet evident. Suitable grouse habitat is still available in the PFRA pasture so perhaps the species has fallen below the threshold at which predation and hunting pressure exceed its reproductive capacity. If present trends continue, Sharp-tailed Grouse may be headed for extirpation, a lamentable loss, but we are cautiously optimistic, having seen a few more birds during this past summer. Surprisingly, Gray Partridge have not rebounded, remaining well below population levels prior to the census; only four were observed on the last count. Perhaps another predator, dare we say "whoo," is at work.

Climate change: One of the biggest differences that we have witnessed since the early seventies is the lack of snow cover and milder temperatures. (There hasn't been a snowy winter since 1973.) Perhaps this explains the addition of new species like Redbreasted Nuthatches, Northern Flickers, Common Grackle and Northern Harriers. It may be that Cedar Waxwings are acclimatizing, whereas Bohemians shun the new "Banana Belt". We haven't lost crops under the snow in the past two decades, so vole and owl populations haven't erupted as they did in the late sixties. With less snow cover, one might have expected more Horned Larks but this hasn't happened. We're into the third year of a deep drought, and the period leading up to the last count was one of the warmest and driest on record. ${ }^{6}$ In 2001, record numbers of CBC participants turned out across Saskatchewan, and a total of 113 species were recorded, the second highest ever. ${ }^{4}$
Changing cultural practices: Public attitudes and government policy influence habitats and wildlife populations in various ways, from species composition of shelterbelts to grazing practices on the PFRA pasture. Few people plant Carrragana and Manitoba Maple shelterbelts anymore, but Blue Spruce has become popular and well established around many farmyards, and it provides better shelter than most tree species. As the human population ages and few new homes and yards are created, the initiative to plant ornamental trees such as crabapples, birch and mountain ash has waned, and "orchards" have declined and disappeared. In the early seventies, a defoliant (Agent Orange it was rumored) was applied widely on PFRA pastures to eliminate brush, but the government has since recognized the wildlife value of these pastures and the practice of spraying has ceased.

Changing attitudes: The annual Christmas bird count was initiated by the Audubon Society as an alternative to the blood sport of bagging species. It's now considered a healthy, socially-acceptable winter sport, engaged in by thousands across North America. It's a great excuse to wear off the gluttony of the season, as well as providing spiritual satisfaction (the peace and quiet of an aspen grove is a fine antidote to the hubbub of the exalted turkey and tree). In a community once noted for its Christmas and Boxing Day spirit, it's a celebration of survival at the frigid apex, bringing together kindred souls.

Biological diversity: "Biodiversity" is the buzzword of our times, synonymous with natural, the antithesis of man-made. In fact, human agricultural settlement of the prairies has enhanced avifaunal diversity over the native state. In spite of, or because of us, the adaptable species endure, even prosper. We have created diversity, both consciously and unconsciously.

Thirtieth CBC Anniversary: The thirtieth annual count on December $31^{\text {st }}, 2001$, 
produced only 12 species, one of our lowest counts ever, despite thorough coverage. Surprisingly, there were no chickadees, woodpeckers or waxwings. A heavy hoar frost shrouded the aspen groves, limiting visibility, but not to the extent that it would explain the absence of these species. Waxwings were noticeably absent throughout November and December, and the crop of Mountain Ash berries and crabapples remained untouched. A new species, the Purple Finch, has been added to our list, and a raven was recorded for the second year in a row. We searched thoroughly in the PFRA pasture but could not find any sign of Sharp-tailed Grouse, the second year in a row. Hopefully our provincial icon is not headed the same way as the Greater Prairie-Chicken. Only four Gray Partridges were seen, one of the lowest counts, despite the fact that only two fox tracks were recorded. Most of the magpies that we counted were at the garbage dump, even though the provincial ban on burning garbage was recently repealed, due to burgeoning rat populations.

One of the more interesting sightings was of four moose, three bulls and a cow, recent invaders, reminding us that they're a boreal species that prospers in pioneering ecosystems and adapts well to human culture. $^{3}$ Not only do deer play with the antelope near the apex of Palliser's Triangle, they actually waltz around with moose, like no other place on earth. Macounian optimism prevails despite the Palliserian drought.

With this, we celebrate the sixtieth anniversary of this Saskatchewan tradition, and salute all those intrepid individuals across this vast province who constitute the spirit and the vision of Nature Saskatchewan.

\section{Acknowledgements}

Many observers participated over the decades and not all can be named. Our families, including Bob, Val, Estelle, Graeme, Liam, Laura, Theron, Gavin, Sandra, Kelly, Robbie, Beverly, Brent,
Dustin, and Levi, participated as did many friends, including Bev and Don Einarson, Bill Frey, Harvey Rozzlein, Glenn, Don and Travis Martfeldt. Theron Finley helped to enter the data. Special thanks to Anna Leighton for her fine editing skills.

\section{In fond memory of Wayne C. Harris.}

1. FINLEY, K. and K. FINLEY. 1982. A decade of Christmas bird counts in the aspen parkland. Blue Jay 40 (1) : 31-33.

2. FINLEY, K. 1996. The red fox invasion and other changes in wildlife populations in west-central Saskatchewan since the 1960s. Blue Jay 54 : 206 - 210.

3. GEIST, V. 1999. Moose: behavior, ecology and conservation. Voyageur Press Inc., Stillwater, Minnesota.

4. HARRIS, W. C. 2001. 59 th annual Saskatchewan Christmas bird count -2000 . Blue Jay 59 (1) : 2 - 28.

\section{LUSELAND HISTORICAL SOCIETY.} 1983. Luseland: Hub and Spokes. Volume 1. 528 p.

6. MITTLESTAEDT, M. 2001. Welcome to the great warm north. Globe and Mail Newspaper. November 28, 2001.

7. RENAUD, W. and G. WAPPLE. 1977. A review of Saskatchewan Christmas bird counts: 1942-1976 (Part 1). Blue Jay 35 (4) : 224 239.

8. RENAUD, W., G.WAPPLE and R. WAPPLE. 1988. A summary of Saskatchewan Christmas Bird Counts: 1942 - 1986. Blue Jay 46 (1) : 29 - 33.

9. SPRY, I.M. 1968. The Palliser Papers 1857- 60. The Champlain Society. Toronto. 694 p. \& xix.

10. WAISER, W. 1989. The Field Naturalist: John Macoun, the Geological Survey, and Natural Science. University of Toronto Press. $253 \mathrm{p}$. 